\title{
PENINGKATAN GIZI SEIMBANG MELALUI KEGIATAN KREASI MAKANAN
}

\author{
Sumiatun $^{1}$, Dita Primashanti Koesmadi ${ }^{2}$, Arwendis Wijayanti ${ }^{3}$ \\ PG PAUD STKIP Modern Ngawi \\ sumiatunmeo14@gmail.com¹,dita.prima23@gmail.com², arwendiswijayanti@gmail.com \\ Sumiatun, Dita Primashanti Koesmadi, Arwendis Wijayanti. (2021). Peningkatan Gizi Seimbang melalui Kegiatan \\ Kreasi Makanan. Jurnal Pelita PAUD, 5(2), 178-183. \\ doi: https://doi.org/10.33222/pelitapaud.v5i2.1305
}

Diterima: 15-04-2021

Disetujui: 25-05-2021

Dipublikasi: 11-06-2021

\begin{abstract}
Abstrak: Mendasar masalah dilapangan, ditemukannya anak-anak yang menyukai jajanan mengandung bahan pengawet dan MSG (Monosodium Glutamat) dimana makanan tersebut dapat membahayakan kesehatan anak. Sehingga diadakan penelitian dengan tujuan mendeskripsikan proses pelaksanaan dan peningkatan gizi seimbang anak usia dini melalui kegiatan kreasi makanan pada TK Nurul Ummah 19 Klempun Ngraho Bojonegoro. Metode Penelitian yang digunakan adalah Penelitian Tindakan Kelas kolaboratif dengan menggunakan modifikasi model Kemmis dan Mc Taggart. Hasil penelitian ini menunjukkan proses pelaksanaan kegiatan kreasi makanan untuk peningkatan gizi seimbang anak meliputi menyebutkan macam-macam makanan yang mengandung gizi seimbang; membuat kreasi makanan dengan peningkatan sebesar $75 \%$ melalui 2 siklus yaitu kondisi awal pra siklus dipersentase 35\% atau 7 dari 20 anak pada kriteria berkembang sangat baik, siklus I yaitu $65 \%$ atau 14 dari 20 anak pada kriteria berkembang sesuai harapan, siklus II yaitu 90\% atau 18 dari 20 anak pada kriteria berkembang sangat baik.
\end{abstract}

Kata Kunci: Gizi Seimbang, Kreasi Makanan, Anak Usia 5-6 Tahun, Penelitian Tindakan Kelas

Abstract : Based on the problem in the field, it was found that children who like snacks containing preservatives and MSG (Monosodium Glutamate) were found to be harmful to children's health. So that the research was held with the aim of describing the process of implementing and increasing balanced nutrition in early childhood through food creation activities at TK Nurul Ummah 19 Klempun Ngraho Bojonegoro. The research method used was collaborative classroom action research using a modified model of Kemmis and Mc Taggart. The results of this study indicate the process of implementing food creation activities to improve children's balanced nutrition includes mentioning the kinds of foods that contain balanced nutrition; making food creations with an increase of $75 \%$ through 2 cycles, namely: the initial conditions of the pre-cycle percentage of 35\% or 7 out of 20 children on the criterion of developing very well, the first cycle of $65 \%$ or 14 out of 20 children on the criteria developing according to expectations, cycle II, namely $90 \%$ or 18 of 20 children in very well developed criteria.

Keyword: balanced nutrition, food creation, children aged 5-6 years, classroom action research.

http://jurnal.upmk.ac.id/index.php/pelitapaud

\section{PENDAHULUAN}


Anak usia dini adalah anak yang baru dilahirkan sampai usia 6 tahun atau sering disebut dengan istilah Golden Age (Akbar, 2020). Menurut Syafi'ie (2011) anak usia ini adalah kelompok anak yang berada dalam proses pertumbuhan dan perkembangan yang bersifat unik. Mereka memiliki pola pertumbuhan dan perkembangan yang khusus sesuai dengan tingkat pertumbuhan dan perkembangannya.

Pendidikan anak usia dini harus dipersiapkan secara terencana dan bersifat holistik-integratif agar di masa emas perkembangan anak mendapatkan stimulus yang utuh, untuk mengembangkan berbagai potensi yang dimilikinya. Upaya yang dapat dilakukan dalam rangka pengembangan potensi tersebut melalui program pendidikan yang terstruktur (Azizah et al., 2020)

Pengoptimalan daya pikir dan otak anak tak lepas dari gizi yang diperoleh anak sejak dini (Noorlaila, 2010). Perkembangan anak pada hakekatnya telah dimulai sejak anak dilahirkan kedunia, bahkan sebagian besar pakar pendidikan meyakini bahwa perkembangan seorang anak dimulai sejak terjadinya konsepsi yang merupakan pertemuan antara sel telur dengan sel sperma dari kedua orang tua hal ini dikemukakan oleh Graimes (2005). Karena itu perlunya memperhatikan gizi anak dari ibu yang sedang hamil sampai anak lahir hingga dewasa. Anak-anak yang kurang mendapatkan pemenuhan gizi yang baik tentunya akan mengalami keterlambatan dalam pertumbuhan dan perkembangan. Anak-anak dengan gizi yang buruk akan berdampak bagi pertumbuhan fisik maupun bagi pertumbuhan mentalnya.

Gizi buruk adalah bentuk terparah (akut), merupakan keadaan kurang gizi tingkat berat yang disebabkan oleh rendahnya tingkat konsumsi energi, protein serta makanan sehari-hari dan terjadi dalam waktu yang cukup lama. Itu ditandai dengan status gizi sangat kurus (menurut berat badan terhadap tinggi badan) dan hasil pemeriksaan klinis menunjukkan gejala marasmus, kwashiorkor atau marasmik-kwashiorkor. Bila jumlah asupan zat gizinya sesuai dengan kebutuhan yang dibutuhkan oleh tubuh disebut seimbang (gizi baik), tetapi bila asupan zat gizi yang dibutuhkan oleh tubuh rebih rendah maka disebut gizi kurang, sedangkan bila asupan zat gizi yang dibutuhkan oleh tubuh sangat kurang disebut gizi buruk. Keadaan kurang zat gizi tingkat berat yang disebabkan rendahnya konsumsi energi dan protein dalam waktu cukup lama yang ditandai dengan berat badan menurut umur yang berbeda hal ini dikemukakan oleh Merryana Adriani (2016).
Konsumsi makanan sangat mempengaruhi terhadap status gizi seseorang terutama anak. Status gizi yang baik dan optimal terjadi apabila tubuh memperoleh cukup zat-zat gizi yang diperlukan secara efisien sehingga memungkinkan pertumbuhan fisik, perkembangan otak, kemampuan kerja dan kesehatan secara umum pada tingkat setinggi mungkin. Perkembangan otak anak sangat mempengaruhi dan menentukan bagi perkembangan aspek-aspek lainnya. Status gizi yang kurang terjadi apabila tubuh mengalami kekurangan satu atau lebih dari zat-zat gizi yang esensial. Makanan yang baik tentunya makanan yang harus mempunyai kandungan berbagai zat gizi yang sangat penting dan diperlukan di dalam tubuh, termasuk makanan yang di konsumsi oleh anak-anak seharusnya juga mengandung nilai-nilai gizi yang sangat penting untuk kesehatan, kecerdasan dan memberikan stimulasi dalam tumbuh kembang anak Sejalan dengan hal tersebut diatas maka perlu adanya pemahaman tentang pentingnya gizi yang seimbang terhadap anak hal ini dikemukakan oleh Septikasari(2018).

Menu seimbang adalah konsumsi makanan untuk memenuhi kebutuhan tubuh akan zat gizi. Kekurangan gizi pada salah satu makanan dengan pemberian menu seimbang dapat dicukupi oleh makanan lain. Untuk itu pemberian menu seimbang dengan makanan yang beraneka ragam sangat dibutuhkan dalam memenuhi kecukupan gizi (Lesmono, n.d.).

Keaneragamanan makanan sebagai sumber tenaga yaitu padi-padian dan umbi-umbian. Kedua, sumber zat pengatur yaitu sayuran dan buah-buah. Ketiga sumber zat pembangun yaitu kacang-kacangan, makanan hewani dan hasil olahan.

Pembelajaran yang diterapkan di TK Nurul Ummah 19 Klempun sudah menggunakan kurikulum 2013 namun kegiatan kreasi makanan yang digunakan dalam proses pembelajaran masih kurang mendukung bagi perkembangan anak, khususnya dalam peningkatan gizi seimbang pada anak. Berdasarkan hasil observasi awal di lapangan gizi seimbang anak masih kurang. Hal ini terbukti dari 20 anak masih banyak anak yang belum menyukai dari makanan seimbang. Hal ini di buktikan dengan penilaian yang ada di laporan perkembangan anak didik sebanyak 7 anak menyukai makanan seimbang dan sisanya sebanyak 13 anak tidak menyukai makanan seimbang, maka peneliti menyiapkan beberapa kegiatan yang mendukung kegiatan peningkatan gizi seimbang anak dalam memecahkan masalah yang menggunakan metode kreasi makanan yang melibatkan pendidik dan orangtua atau wali murid. 


\section{Gizi Seimbang}

Pertumbuhan dan perkembangan anak sangat erat kaitannya dengan makanan yang dikonsumsi oleh anak sehari-hari. Menurut Soemanto (2006) bahwa pertumbuhan yang berhubungan dengan tinggi dan berat badan sangat dipengaruhi oleh kondisi internal, misalnya gizi yang diperoleh dari makanan, perangai dan lain-lain. Menurut Menteri Pendidikan Dan kebudayaan (2014) dalam peraturan menteri pendidikan dan kebudayaan republik Indonesia nomor 137 tahun 2014 pasal 7 tentang standar nasional pendidikan anak usia dini bahwa tingkat pencapaian perkembangan anak merupakan pertumbuhan dan perkembangan anak yang dapat dicapai pada rentang usia tertentu. Pertumbuhan anak sebagaimana dimaksud merupakan pertambahan berat dan tinggi badan yang mencerminkan kondisi kesehatan dan gizi yang mengacu pada panduan pertumbuhan anak dan dipantau menggunakan instrumen yang dikembangkan oleh Kementerian Kesehatan.

Hikmawati (2012) mendefinisikan Gizi (Nutrition) adalah suatu proses organisme menggunakan makanan yang dikonsumsi secara normal melalui proses digesti, absorpsi, transportasi, penyimpanan, metabolisme dan pengeluaran zat-zat yang tidak digunakan, untuk mempertahankan kehidupan, pertumbuhan dan fungsi normal dari organ-organ, serta menghasilkan energi. Gizi berkaitan dengan perkembangan otak, kemampuan belajar, produktivitas kerja.

Gizi yang seimbang bukan saja untuk pertumbuhan dan perkembangan anak itu sendiri tetapi juga sangat berguna untuk meningkatkan daya tahan tubuh, daya ingat dan meningkatkan kecerdasan anak. Makin baik gizi dari makanan yang dikonsumsi oleh anak, maka akan semakin baik pula perkembangan fisik, sejalan dengan semakin baik perkembangan perkembangan fisik anak, akan meningkatkan daya tahan tubuh anak serta meningkatkan kecerdasan. Ketika daya tahan tubuh anak semakin meningkat, anak tidak akan mudah terserang penyakit dan perkembangan anak akan semakin optimal dan ketika gizi anak buruk maka daya tahan tubuh anakpun melemah(Widjaja, 2002). Menurut Syafrizar \& Welis (2009) bahwa jenis zat gizi seimbang yang terkandung dalam makanan kita adalah karbohidrat, lemak, protein, vitamin, mineral dan air. Makanan yang dikonsumsi oleh anak harus mengandung zat-zat gizi yang dibutuhkan oleh tubuh. Zat-zat gizi yang dibutuhkan oleh tubuh itu yaitu karbohidrat, lemak, protein, vitamin, mineral dan air. Kebiasaan dan kesukaan anak terhadap makanan mulai dibentuk sejak kecil. Anak diperkenalkan dengan berbagai jenis makanan mulai sejak usia dini.

Anak-anak dibiasakan mengkonsumsi makanan yang sehat dan mengandung gizi yang seimbang dan variatif. Aneka bahan makanan yang diberikan secara bertahap dapat merangsang alat pencernaan untuk memproduksi enzim-enzim yang diperlukan (Uripi, 2004). Zat-zat gizi yang berperan dalam tubuh diperoleh dari makanan yang dikonsumsi oleh anak, zat gizi tersebut antara lain adalah karbohidrat, lemak, protein mineral, asam folat dan lain-lain. Selain dari zat gizi yang dibutuhkan oleh tubuh anak juga memerlukan olahraga, membiasakan anak untuk makan sayuran, buahbuahan, ikan. Selain itu lebih baik menghindari makanan dengan mutu yang buruk, tinggi gula, makanan yang mengandung pengawet juga tidak bagus untuk anak. Selain itu anak-anak perlu mengkonsumsi makanan yang mengandung zat besi dan anak-anak dibiasakan untuk cukup minum air putih dan menghindari minuman ringan berkarbonasi (Graimes, 2005).

Konsep kesehatan anak sangat erat kaitannya dengan makanan yang dikonsumsi. Makanan sangat berpengaruh terhadap kesehatan manusia. Apabila anak mengkonsumsi makanan yang berlebihan akan menyebabkan ancaman bagi kesehatan anak. Kegemukan salah satu akibat dari mengkonsumsi makanan yang berlebihan, sedangkan dibalik kegemukan banyak tersimpan berbagai penyakit. Anak yang terbiasa mengkonsumsi makanan yang kurang terjaga kebersihannya akan menyebabkan anak-anak mudah terserang penyakit dan berakibat dengan kondisi daya tahan tubuh anak. Mudah terserang diare dan penyakit lainnya. Sedangkan dalam jangka panjang anak-anak sering mengkonsumsi makanan yang mengandung pengawet dan zat-zat aditif akan mengakibatkan kerusakan dalam jaringan tubuh sehingga kesehatan akan terganggu (TM, 2011).

Akibat dari mengkonsumsi makanan-makanan yang berbahaya dan makanan yang mengandung zat-zat aditif yang berbahaya bagi kesehatan, banyak dari anak-anak yang terserang penyakit diare, dan muntaber. Kesehatan anak menjadi terganggu karena anak terlalu sering mengkonsumsi makanan yang berbahaya bagi kesehatan dan tubuh anak. Pola makan yang buruk dan kurangnya pemahaman tentang gizi seimbang mengakibatkan anak-anak terserang penyakit. Anak-anak yang mudah terserang penyakit akan mengganggu pertumbuhan dan perkembangan anak pada tahap selanjutnya Bahaya dari anak yang tidak mengkonsumsi makanan yang mengandung gizi seimbang akan ada banyak penyakit yang bisa timbul jika anak 
kekurangan gizi atau makanan yang anak makan tidak mengandung gizi seimbang. Anak dikatakan sehat apabila kebutuhan gizinya terpenuhi, akan tetapi di TK Nurul Ummah 19 Klempun ditemukan masalah dimana anak-anak lebih suka makanan dan jajanan yang mengandung bahan pengawet dan MSG (Monosodium Glutamat). Untuk mengatasi masalah tersebut perlu diadakan suatu cara dan inovasi baru yaitu melalui kreasi makanan sehingga dapat menarik minat anak terhadap makanan yang mengandung gizi seimbang.

\section{Kreasi Makanan}

Seni membentuk kreasi makanan adalah seni menampilkan masakan yang diadopsi dari Jepang. Bentuk kreasi ini digunakan sebagai salah satu cara untuk menarik minat anak-anak terhadap makanan yang mengandung gizi yang baik dan mengandung gizi yang seimbang untuk anak-anak yang akan berguna untuk pertumbuhan dan perkembangan anak yang semakin optimal. Anak-anak lebih menyukai akan hal-hal yang unik dan menarik. Makanan yang dikemas dengan penyajian yang menarik dan unik akan dapat mengundang selera makan dari anak. Penyajian makanan yang kreatif dan sesuai dengan minat anak akan memudahkan bagi orang tua untuk menyajikan makanan yang mengandung gizi yang seimbang untuk anak. Diharapkan dengan kegiatan kreasi makanan anak akan lebih memahami tentang makanan yang mengandung gizi yang seimbang dan lebih menyukai makanan yang menyehatkan. Salah satu cara untuk mengatasi agar anak-anak mengkonsumsi makanan yang mengandung nilai gizi yang tinggi adalah dengan mengkreasikan makanan tersebut menjadi bentuk-bentuk yang menarik bagi anak (Novitasari, 2009).

Membentuk kreasi makanan sesungguhnya suatu seni yang digunakan untuk memudahkan orang tua dalam menyajikan makanan yang menyehatkan untuk anak-anak. Sebagian besar orang tua mengeluh karena anak-anaknya susah makan, jadi butuh tips agar makanannya lebih bervariasi. Ketika orang tua sudah menyediakan makanan yang bervariasi terkadang anak-anak tidak menyentuh sama sekali makanan yang dilakukan.

Membentuk kreasi makanan juga termasuk melatih motorik halus anak. motorik halus merupakan gerakan otot halus bagian tubuh tangan, lengan tangan, pergelangan tangan, dan jari-jemari yang terkordinasi dengan mata untuk memenuhi tugastugas perkembangan yang membutuhkan ketepatan, kepresisian, dan ketangkasan.

\section{METODE PENELITIAN \\ Jenis Penelitian}

Metode yang digunakan dalam penelitian ini adalah metode penelitian tindakan kelas. Penelitian tindakan (action research) yang sudah dilakukan ini menggunakan prosedur yang dikemukakan oleh Stephen Kemmis dan Mc.Taggart.

\section{Waktu dan Tempat Penelitian}

Penelitian ini menganalisis cara peningkatan gizi seimbang melalui kreasi makanan di TK Nurul Ummah 19 Klempun Ngraho Bojonegoro usia 5-6 tahun dengan jumlah 20 anak. Penelitian ini dilaksanakan pada semester II, tahun ajaran 2020/2021 yaitu bulan maret 2021.

\section{Prosedur}

Peneliti merencanakan tindakan dengan dua siklus dan setiap siklus terdiri dari tiga kali pertemuan setiap siklusnya sesuai dengan prosedur yang telah ditentukan. Masing-masing siklus terdiri dari empat komponen yaitu, perencanaan (planning), tindakan (action), pengamatan (observe), dan refleksi (reflection). Pada siklus ini peneliti menetapkan indikator keberhasilan berdasarkan permasalahan yang sedang diteliti yaitu tentang gizi seimbang anak usia dini.

\section{Data, Intrumen, dan Teknik Pengumpulan Data}

Jenis instrumen yang digunakan sebagai alat pengambilan data dalam penelitian tindakan ini adalah instrumen yang mengacu pada gizi seimbang anak usia 5-6 tahun dengan teknik observasi melalui Catatan Observasi Awal. Instrumen dikembangkan dalam bentuk ceklis dengan rentangan skor 1-4. Teknik pengumpulan data yang digunakan dalam penelitian ini adalah lembar pengamatan atau observasi dan dokumentasi (Kementerian Pendidikan Nasional, 2014).

\section{Teknik Analisi Data}

Penelitian ini termasuk penelitian kuantitatif dan kualitatif. Secara kuantitatif data yang terkumpul dianalisa secara deskriptif presentase. Tingkat perubahan yang terjadi diukur dengan persen. Jumlah anak yang mampu mencapai indikator keberhasilan dibagi jumlah seluruh anak yang diteliti dikalikan seratus persen, maka diketahui persentase dari tingkat keberhasilan tindakan. Indikator penilaian pada gizi seimbang anak meliputi : 1) kemampuan berkreasi makanan, 2) kemampuan kreativitas, 3) kemampuan tentang kreasi makanan, 4) kemampuan minat mengkomsumsi makanan.

\section{HASIL DAN PEMBAHASAN}

Hasil penelitian menunjukkan bahwa melalui kegiatan kreasi makanan dapat meningkatkan gizi seimbang anak usia dini pada kelompok B TK Nurul 
Ummah 19 Klempun. Hasil penelitian dan pembahasan sebagai berikut :

Kegiatan pembelajaran yang diberikan guru khususnya tentang gizi seimbang sebelum tindakan yaitu menggunakan metode pemberian makanan tanpa kreasi. Metode tersebut belum dapat meningkatkan gizi seimbang anak secara keseluruhan. Hasil observasi yang dilakuka, dapat diketahui bahwa gizi seimbang anak masih rendah, terbukti dengan data sebagai berikut :

Tabel 1 Rekapitulasi data gizi seimbang anak sebelum tindakan

\begin{tabular}{clcc}
\hline \multirow{2}{*}{ Kriteria } & \multirow{2}{*}{ Kategori } & \multicolumn{2}{c}{ Prasiklus } \\
\cline { 3 - 4 } & & Anak & $\%$ \\
\hline BSB & Sangat baik & 0 & 0 \\
\hline BSH & Baik & 7 & $35 \%$ \\
\hline MB & Cukup & 13 & $65 \%$ \\
\hline BB & Kurang & 0 & 0 \\
\hline
\end{tabular}

Rekapitulasi data diatas menunjukkan bahwa $35 \%$ dalam kriteria baik dan $65 \%$ dalam kriteria cukup. Hal ini menunjukkan bahwa gizi seimbang anak masih rendah. Dari hasil obeservasi rendahnya gizi seimbang anak di TK Nurul Ummah 19 Klempun dikarenakan tidak diterapkannya metode kreasi makanan dalam kegiatan pembelajaran tentang gizi seimbang. Sehingga hasilnya anak tidak menyukai makanan tersebut, karena makanan tersebut kurang menarik dan kelihatan tidak enak.

Pada siklus I terdiri dari tahap perencanaan, tindakan dan observasi serta refleksi. Tahap perencaaan pada siklus I yaitu merencanakan dan menyusun RPPH yang akan digunakan sebagai acuan dalam pelaksanaan pembelajaran.

Tabel 2. Rekapitulasi data gizi seimbang anak pada siklus I.

\begin{tabular}{clcc}
\hline \multirow{2}{*}{ Kriteria } & \multirow{2}{*}{ Kategori } & \multicolumn{2}{c}{ Prasiklus } \\
\cline { 3 - 4 } & & Anak & $\%$ \\
\hline BSB & Sangat baik & 0 & 0 \\
\hline BSH & Baik & 14 & $70 \%$ \\
\hline MB & Cukup & 6 & $30 \%$ \\
\hline BB & Kurang & 0 & 0 \\
\hline
\end{tabular}

Rekapitulasi data diatas menunjukkan bahwa $70 \%$ dalam kriteria baik dan 30\% dalam kriteria cukup. Berdasarkan hasil yang dicapai pada Siklus I dapat diketahui ada peningkatan gizi seimbang anak. Hasil kegiatan kreasi makanan pada siklus pertama, diketahui gizi seimbang anak. Hasil menunjukkan bahwa gizi seimbang anak baik meskipun sebagian besar anak masih belum mampu berkreasi dengan baik dan belum mau mengkonsumsi hasil kreasinya. Dalam pelaksanaan tindakan siklus 2 peneliti tidak menemui kendala yang berarti. Hal tersebut dikarenakan sudah dilakukan perbaikan rencana sebelum siklus 2 dilaksanakan.

Tabel 3 Rekapitulasi data gizi seimbang anak pada siklus II.

\begin{tabular}{clcc}
\hline \multirow{2}{*}{ Kriteria } & \multirow{2}{*}{ Kategori } & \multicolumn{2}{c}{ Prasiklus } \\
\cline { 3 - 4 } & & Anak & $\%$ \\
\hline BSB & Sangat baik & 11 & $55 \%$ \\
\hline BSH & Baik & 7 & $35 \%$ \\
\hline MB & Cukup & 2 & $10 \%$ \\
\hline BB & Kurang & 0 & 0 \\
\hline
\end{tabular}

Rekapitulasi data diatas menunjukkan bahwa $11 \%$ dalam kriteria sangat baik, $35 \%$ dalam kriteria baik dan $10 \%$ dalam criteria cukup. Berdasarkan tabel 3 dijelaskan bahwa hasil pada siklus kedua, diketahui bahwa anak mengalami peningkatan dibandingkan siklus satu. Sebagian besar anak sudah dapat berkreasi. Anak juga mau menikmati makanan hasil kreasinya sendiri dengan lebih lahap dibandingkan sebelumnya.

Penelitian yang dilakukan melalui dua siklus dan setiap siklus terdiri dari tiga kali pertemuan, terlihat bahwa kegiatan kreasi makanan dapat meningkatkan gizi seimbang anak kelompok B di TK Nurul Ummah 19 klempun. Peningkatan tersebut dapat dibuktikan dari kriteria hasil belajar anak sebelum tindakan dan sesudah tindakan, dimana setiap siklus menunjukkan peningkatan.

Penelitian dianggap sudah berhasil dan dihentikan karena sebagian besar anak sudah mengalami peningkatan sesuai dengan indikator keberhasilan yang ditetapkan oleh peneliti.

Kegiatan membentuk kreasi makanan dilaksanakan dalam 2 siklus, pada siklus pertama dan siklus ke dua ada 4 aspek penilaian yaitu: anak mampu mengkreasikan bentuk makanan, anak mampu berperilaku kreatif, anak mampu menjawab pertanyaan tentang manfaat makanan, serta meningkatkan gizi seimbang pada anak melalui kegiatan membentuk kreasi makanan. Pada pra siklus anak mampu mengkreasikan bentuk makanan sebesar 35\%. Pada siklus 1 anak mengalami peningkatan sebesar 70\%. Pada siklus 2 mengalami peningkatan sebesar $90 \%$.

Berdasarkan pemaparan hasil penelitian dan hasil pembahasan dapat disimpulkan bahwa penerapan kegiatan kreasi makanan dapat meningkatkan gizi seimbang anak kelompok B TK Nurul Ummah 19 Klempun. Hal tersebut sejalan dengan pendapat Azizah et al (2020) menyatakan bahwa kegiatan kreasi menu makanan bergizi untuk anak usia dini mampu mengembangkan gizi bagi anak. 


\section{SIMPULAN}

Penelitian tindakan kelas tentang peningkatan gizi seimbang melalui kegiatan kreasi makanan pada kelompok B TK Nurul Ummah 19 Klempun telah dilaksanakan dalam dua siklus kegiatan, Berdasarkan paparan data dan hasil penelitian, maka dapat disimpulkan beberapa hal sebagai berikut: 1) Hal ini dapat ditunjukkan dari meningkatnya hasil pembelajaran dari anak melalui prosentase data pra siklus yaitu sebesar 35\%, yaitu sebanyak 7 anak dari jumlah keseluruhan 20 anak. Siklus I sebesar 70\%, yaitu sebanyak 14 anak dari jumlah keseluruhan 20 anak dan pada Siklus II sebesar 90\%, yaitu sebanyak 18 anak dari jumlah keseluruhan 20 anak. Sedangkan untuk anak yang tidak tuntas hanya sebanyak 2 anak dan jika dipersentase adalah sebesar $10 \%$. 2) Setelah diterapkannya metode kreasi makanan pada anak kelompok B TK Nurul Ummah 19 Klempun Kecamatan Ngraho kabupaten Bojonegoro Tahun Pelajaran 2020/2021 bahwa gizi seimbang anak mengalami peningkatan. Hal tersebut dapat dilihat dari hasil peningkatan pada tindakan siklus. Sehingga metode kreasi makanan sangat efektif diterapkan untuk meningkatkan gizi seimbang anak.

\section{DAFTAR PUSTAKA}

Akbar, E. (2020). Metode Belajar Anak Usia Dini. Prenada Media.

Azizah, El. N., Tanto, O. D., Naningtias, S. A., \& Rahmawati, R. U. (2020). Indonesian Journal of Community Engagement (IJCE) LPPM-STKIP Modern Ngawi. Indonesian Journal of Community Engagement (IJCE), 2(1), 14-19.

Graimes, N. (2005). Brain foods for kids. New York: Random House.

Hikmawati, I. (2012). Ilmu Dasar Keperawatan (IDK) Pokok Bahasan: Kesehatan Masyarakat, Demografi, kebijakan kesehatan, Epidemiologi, dan Gizi Masyarakat.

Kementerian Pendidikan Nasional. (2014). Permendikbud No 146 Tahun 2014. $\square \square \square, 8(33)$, $37 . \quad$ http://paud.kemdikbud.go.id/wpcontent/uploads/2016/04/Permendikbud-146Tahun-2014.pdf

Lesmono, H. (n.d.). DAFTAR PUSTAKA. Almatsier, $S$ Prinsip Dasar Ilmu Gizi. Gramedia Pustaka Umum. Jakarta.

Menteri Pendidikan Dan kebudayaan. (2014). Standar Nasional Pendidikan Anak Usia Dini. Peraturan Menteri Pendidikan Dan Kebudayaan Republik Indonesia, 13.

Merryana Adriani, S. K. M. (2016). Pengantar gizi masyarakat. Prenada Media.

Noorlaila, I. (2010). Panduan lengkap mengajar PAUD. Yogyakarta: Pinus Book Publisher.

Novitasari, R. (2009). Membuat Bekal Sekolah. Bandung:
Mitra Sarana.

Septikasari, M. (2018). Status gizi anak dan faktor yang mempengaruhi. UNY Press.

Soemanto, W. (2006). Pendidikan Psikologi. Jakarta: PT. Rineka Cipta.

Syafi'ie, K. (2011). Pendidikan Anak Usia Dini dalam Islam/Mansur.

Syafrizar, \& Welis, W. (2009). Gizi Olahraga. Ilmu Gizi:Teori \& Aplikasi, 1-441.

TM, E. (2011). Healthy Habits You Must Know. Jakarta: PT Buku Kita.

Uripi, V. (2004). Menu sehat untuk balita. Jakarta: Puspa Swara.

Widjaja, M. C. (2002). Gizi tepat untuk perkembangan otak dan kesehatan balita. Jakarta: Kawan Pustaka, 87-89. 